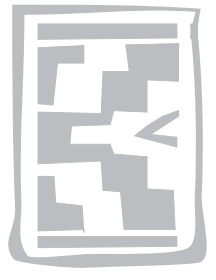

\title{
Immunoreactivities to protein gene product 9.5, neurofilament protein and neuron specific enolase in nerves in the oviduct of the sexually immature ostrich, Struthio camelus
}

\author{
M.-C. MADEKUROZWA* \\ Department of Anatomy and Physiology, Faculty of Veterinary Science, University of Pretoria \\ Onderstepoort, 0110 South Africa
}

\begin{abstract}
MADEKUROZWA, M.-C. 2006. Immunoreactivities to protein gene product 9.5, neurofilament protein and neuron specific enolase in nerves in the oviduct of the sexually immature ostrich, Struthio camelus. Onderstepoort Journal of Veterinary Research, 73:131-137

The present study investigated the distribution of nerves in the oviduct of the sexually immature ostrich. The presence of protein gene product 9.5, neurofilament protein and neuron specific enolase nerve fibres were demonstrated in the infundibulum, magnum, isthmus, shell gland and vagina. Nerve fibres containing protein gene product 9.5 , neuron specific enolase and neurofilament protein were particularly numerous in the tunica muscularis and intermuscular connective tissue areas of the shell gland and vagina. The presence of a large number of nerves in these oviductal regions is probably important in the coordination of muscle contraction. An interesting finding of the study was the presence of protein gene product 9.5 and neuron specific enolase immunopositive nerve fibres in the walls of blood vessels. It is likely that these nerves are autonomicin nature and play a role in the regulation of blood flow. This study has shown the presence of an extensive neural network in the oviduct of the ostrich. In addition, the results of the investigation have shown that the neuronal markers protein gene product 9.5 , neurofilament protein and neuron specific enolase can be used to demonstate nerve fibres in the ostrich
\end{abstract}

Keywords: Immunohistochemistry, nerves, neurofilament protein, neuron specific enolase, ostrich, oviduct, protein gene product 9.5

\section{INTRODUCTION}

The motility of the oviduct in birds is regulated by hormonal and neural factors (Wechsung \& Houvenaghel 1988). Previous studies on the oviduct of the domestic fowl (Gilbert \& Lake 1963; Costagliola, Mayer, Vittoria, Carrese, Lamanna \& Cecio 1997), the Japanese quail (Arjamaa \& Talo 1983) and the pigeon (Atoji, Mizutani, Yamamoto \& Suzuki 2000) have demonstrated the presence of an extensive neural network

\footnotetext{
* E-mail: madex@op.up.ac.za

Accepted for publication 30 March 2006-Editor
}

in both the intermuscular and muscular regions of the organ. These neural networks are known to play a significant role in the transportation of the egg in the oviduct by co-ordinating muscle contraction (Talo \& Kekalainen 1976; Wechsung \& Houvenaghel 1988). A dysfunction in oviducal motility results in a condition known as egg-binding in which the formed egg is retained within the oviduct (Rosskopf \& Woerpel 1984; Krautwald-Junghanns, Kostka \& Hofbauer 1998). Ruptured oviduct and peritonitis are possible consequences of this condition (Rosskopf \& Woerpel 1984). Although the exact cause of egg-binding is unknown, it is possible that a disturbance in the innervation to the oviduct might be involved. However, before the possible role of the nerves of the oviduct 
Immunoreactivities to protein gene product 9.5, neurofilament protein and neuron specific enolase in ostrich

in this condition can be investigated it is necessary to study their normal distribution within the oviduct.

In mammals plasma levels of oestrogen influence the density of nerves in the female reproductive tract (Haase, Buchman, Tietz \& Schramm 1997; Brauer, Llodra, Scorza, Chavez, Burnstock, Thrasivoulu \& Cowen 1999; Zoubina \& Smith 2001; Zoubina, Mize, Alper \& Smith 2001). Although the effect of oestrogen on the innervation of the avian oviduct is unknown it was decided to use prepubertal ostriches in the present study to avoid any possible effects of high oestrogen levels on oviductal nerve density. The distribution of nerves within the oviduct of these birds was studied using antibodies against protein gene product 9.5 (PGP), neurofilament protein (NP), and neuron specific enolase (NSE).

A marker for afferent nerves, NP, has been identified in the uterus of the human (Khong, Tee \& Kelly 1997), the bovine (Wrobel \& Kujat 1993) and the guinea pig (Alm, Lundberg, Wharton \& Polak 1988a). The general neuronal markers, PGP and NSE, have been utilized to demonstrate nerve fibres in the uterus of the horse (Bae, Corcoran \& Watson 2001) and the guinea pig (Alm, Lundberg, Wharton \& Polak 1988b; Lundberg, Alm, Wharton \& Polak 1988).

\section{MATERIALS AND METHODS}

Fifteen prepubertal female ostriches, with quiescent ovaries, were used in the study. The birds were aged between 12 and 14 months, with body mass of 90$100 \mathrm{~kg}$.

At a commercial ostrich abattoir the ostriches were electrically stunned and exsanguinated. Tissue samples were collected 10-15 min after slaughter from the infundibulum, magnum, isthmus, shell gland pouch and cranial vagina. Five samples were taken from each region. The tissue samples were immersion-fixed in either $4 \%$ paraformaldehyde $(\mathrm{pH} 7.2)$ or Bouin's fluid for $14 \mathrm{~h}$. Some of the samples were fixed in Bouin's fluid because the antibody against protein gene product 9.5 (Dakocytomation, Denmark) is only suitable for use on paraffin sections.

The tissue samples fixed in paraformaldehyde were placed, for $24 \mathrm{~h}$ at $4{ }^{\circ} \mathrm{C}$, in a $30 \%$ sucrose solution made up in $0.01 \mathrm{M}$ phosphate buffered saline solution 1-1 (PBS, pH 7.4). Thereafter, they were snap frozen in OCT compound (Sakura, CA, USA) in an isopentane/dry ice slurry. The samples were then stored at $-80^{\circ} \mathrm{C}$.
The tissue samples fixed in Bouin's fluid were processed routinely for histology and embedded in paraffin wax.

The immunostaining technique was performed on $10 \mu \mathrm{m}$ thick cryostat sections and $5 \mu \mathrm{m}$ thick paraffin sections, using a LSAB-plus kit (Dakocytomation, Denmark). The cryostat sections were air dried for $60 \mathrm{~min}$ at room temperature after which they were rinsed in PBS. Endogenous peroxidase activity in both cryostat and paraffin sections was blocked using a $3 \%(\mathrm{v} / \mathrm{v})$ hydrogen peroxidase solution in water for $5 \mathrm{~min}$. The slides were then rinsed in PBS for $5 \mathrm{~min}$. Thereafter, the paraffin sections were microwaved at $750 \mathrm{~W}$ for three cycles of 5 min each. After being allowed to cool for $20 \mathrm{~min}$ the sections were rinsed with PBS. The paraffin sections were then incubated for $30 \mathrm{~min}$ at room temperature with a polyclonal antibody against PGP (Dakocytomation, Denmark), at a dilution of 1:50. The cryostat sections were incubated for $30 \mathrm{~min}$ with monoclonal antibodies against NP (Dakocytomation, Denmark), and NSE (Dakocytomation, Denmark) at dilutions of 1:75 and 1:50, respectively. After this incubation all the slides were rinsed with PBS and then incubated for 15 min with a biotinylated secondary antibody (LSABplus kit, Dakocytomation, Denmark). Thereafter, the slides were rinsed in PBS and subsequently incubated for $15 \mathrm{~min}$ with the streptavidin peroxidase component of the LSAB-plus kit. Slides were then rinsed in PBS and bound antibody was visualized after the addition of a 3,3'-diaminobenzidine tetrachloride solution (LSAB-plus kit, Dakocytomation, Denmark). Slides were counterstained with Mayer's haematoxylin for $20 \mathrm{~s}$ before being dehydrated in graded concentrations of ethanol.

In the negative controls, the primary antibodies were replaced with either normal mouse or normal rabbit serum. A histological section of nerve was used as a positive control. No background staining was detected in the negative control sections, whilst nerve fibres immunoreactive for PGP, NP and NSE were observed in the positive control sections.

A subjective assessment of the density and distribution of immunoreactive nerves (Bae et al. 2001) was performed under the $X 40$ objective of a light microscope and was graded subjectively as: $-=$ no nerve fibres observed; + = very few nerve fibres observed; $+=$ a small number of nerve fibres observed; $++=a$ moderate number of nerve fibres observed and +++ $=\mathrm{a}$ large number of nerve fibres observed. The relative density of immunoreactive nerves is summarized in Table 1. 
TABLE 1 Relative frequency and distribution of protein gene product 9.5 (PGP)-, neurofilament protein (NP)- and neuron specific enolase-immunoreactive nerves in the oviduct of the ostrich

\begin{tabular}{|c|c|c|c|}
\hline Region of oviduct & Protein gene product & Neurofilament protein & Neuron specific enolase \\
\hline \multicolumn{4}{|l|}{ Infundibulum } \\
\hline $\begin{array}{l}\text { Epithelium } \\
\text { Lamina propria-submucosa } \\
\text { Tunica muscularis } \\
\text { Intermuscular region } \\
\text { Tunica serosa }\end{array}$ & $\begin{array}{l}- \\
- \\
+ \\
+ \\
+\end{array}$ & $\begin{array}{l}- \\
\pm \\
\pm \\
+ \\
\pm\end{array}$ & $\begin{array}{l}- \\
+ \\
+ \\
+ \\
-\end{array}$ \\
\hline \multicolumn{4}{|l|}{ Magnum } \\
\hline $\begin{array}{l}\text { Epithelium } \\
\text { Lamina propria-submucosa } \\
\text { Tunica muscularis } \\
\text { Intermuscular region } \\
\text { Tunica serosa }\end{array}$ & $\begin{array}{l}- \\
+ \\
++ \\
+ \\
\pm\end{array}$ & $\begin{array}{l}- \\
++ \\
++ \\
++ \\
+\end{array}$ & $\begin{array}{l}- \\
+ \\
+ \\
+ \\
\pm\end{array}$ \\
\hline \multicolumn{4}{|l|}{ Isthmus } \\
\hline $\begin{array}{l}\text { Epithelium } \\
\text { Lamina propria-submucosa } \\
\text { Tunica muscularis } \\
\text { Intermuscular region } \\
\text { Tunica serosa }\end{array}$ & $\begin{array}{l}- \\
+ \\
+ \\
+ \\
\pm\end{array}$ & $\begin{array}{l}- \\
\pm \\
++ \\
++ \\
++\end{array}$ & $\begin{array}{l}- \\
++ \\
++ \\
++ \\
++\end{array}$ \\
\hline \multicolumn{4}{|l|}{ Shell gland } \\
\hline $\begin{array}{l}\text { Epithelium } \\
\text { Lamina propria-submucosa } \\
\text { Tunica muscularis } \\
\text { Intermuscular region } \\
\text { Tunica serosa }\end{array}$ & $\begin{array}{l}- \\
++ \\
+++ \\
++ \\
++\end{array}$ & $\begin{array}{l}- \\
++ \\
+++ \\
+++ \\
++\end{array}$ & $\begin{array}{l}- \\
+ \\
+++ \\
+++ \\
++\end{array}$ \\
\hline \multicolumn{4}{|l|}{ Vagina } \\
\hline $\begin{array}{l}\text { Epithelium } \\
\text { Lamina propria-submucosa } \\
\text { Tunica muscularis } \\
\text { Intermuscular region } \\
\text { Tunica serosa }\end{array}$ & $\begin{array}{l}- \\
+++ \\
+++ \\
++ \\
\pm\end{array}$ & $\begin{array}{l}- \\
+ \\
+++ \\
+++ \\
\pm\end{array}$ & $\begin{array}{l}- \\
+ \\
+++ \\
+++ \\
\pm\end{array}$ \\
\hline
\end{tabular}

The density of immunoreactive nerves was graded semiquantitatively as follows: $-=$ none observed; $\pm=$ very few observed; $+=\mathrm{a}$ small number observed; ++ = a moderate number observed; +++ = a large number observed

\section{RESULTS}

Nerve fibres immunoreactive for PGP, NP and NSE were observed in all the oviductal regions studied. Furthermore, immunoreactivity was demonstrated in nerve fibres in all the tissue layers of the oviduct with the exception of the epithelium. In the ostrich, the two layers of the tunica muscularis were separated by a wide connective tissue area, which is referred to as the intermuscular connective tissue area in this study.

\section{Distribution of PGP immunoreactive nerve fibres}

Few PGP-immunoreactive nerve fibres were found in the lamina propria-submucosa of the proximal re- gions of the oviduct (Fig. 1A). In the tunica muscularis the density of nerve fibres containing PGP appeared to be similar in the shell gland and vagina, but lower in the infundibulum, magnum and isthmus (Table 1). Nerve fibres within the muscle bundles coursed parallel to the smooth muscle cells, whilst nerve fibres between the muscle bundles were orientated obliquely (Fig. 1B). Within the intermuscular connective tissue area, nerve bundles containing PGP were seen close to blood vessels. In addition, a few PGP-immunoreactive nerve fibres were occasionally present in the walls of the blood vessels. PGP-immunopositive nerve bundles in the tunica serosa did not appear to be accompanied by blood vessels. 


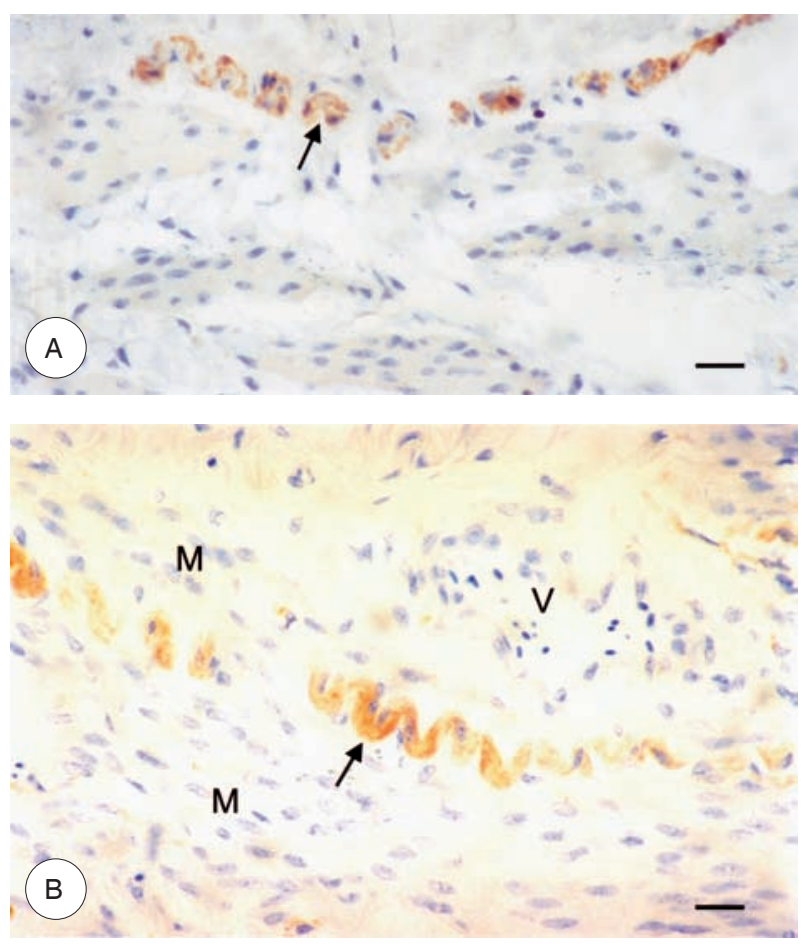

FIG. 1 (A-B) Protein gene product 9.5 (PGP)-immunoreactive nerve fibres in the oviduct of the ostrich

(A) PGP-immunoreactive nerve fibre (arrow) in the lamina propria-submucosa of the magnum. (B) PGP-immunoreactive nerve fibres (arrow) in the tunica muscularis of the isthmus are positioned parallel to the longitudinal axes of the smooth muscle cells (M). Note the blood vessel $(\mathrm{V})$ associated with the nerve

Scale bar $=50 \mu \mathrm{m}$

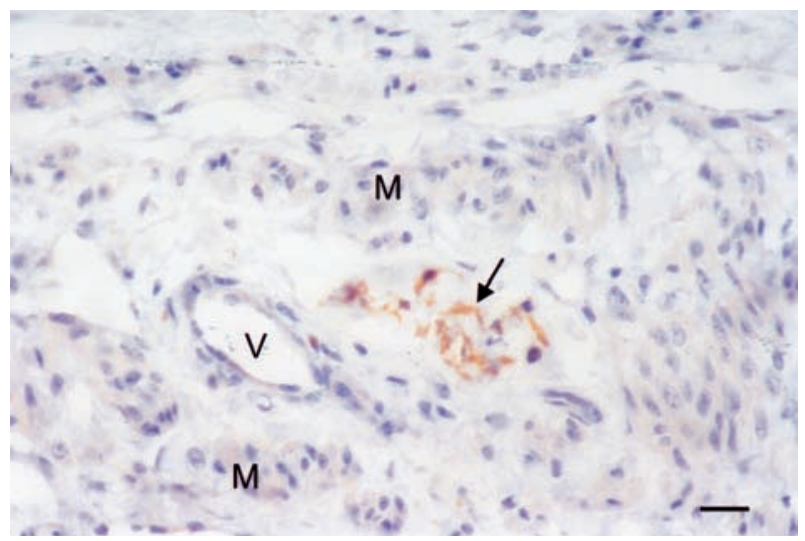

FIG. 2 NP-immunoreactive nerve fibres (arrow) in the intermuscular connective tissue area of the vagina. $\mathrm{V}$ : blood vessel. M: smooth muscle cells

Scale bar $=50 \mu \mathrm{m}$
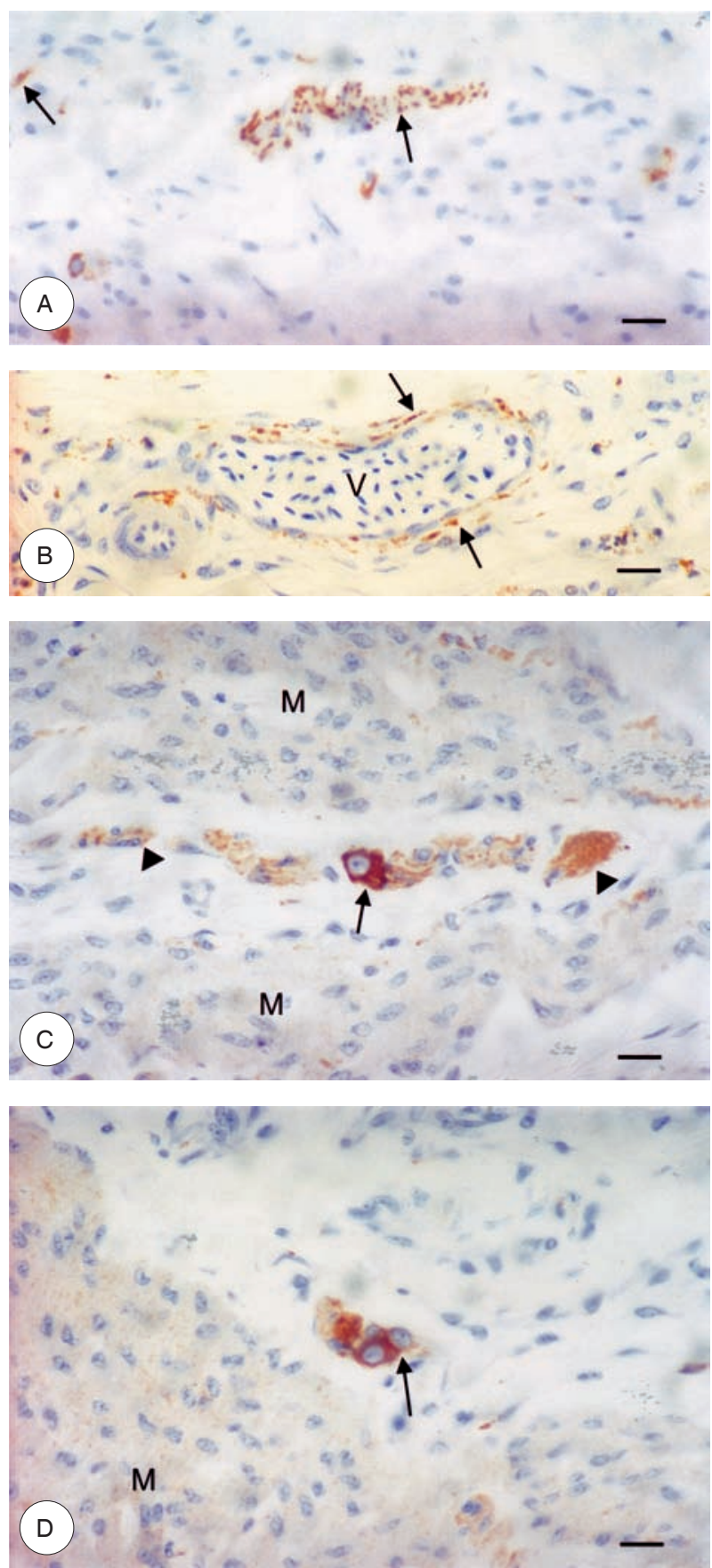

FIG. 3 (A-D) Neuron specific enolase (NSE)-immunoreactive nerve fibres in the oviduct of the ostrich

(A) NSE-immunoreactive nerve fibres (arrow) in the lamina propria-submucosa of the isthmus. (B) NSE-immunoreactive nerve fibres (arrows) distributed in the wall of a blood vessel $(\mathrm{V})$ in the intermuscular connective tissue area of the shell gland. (C) A NSE-immunoreactive nerve cell body (arrow) is observed in a nerve bundle (arrowheads). M: smooth muscle cells. (D) Nerve cell bodies (arrow) with NSE-immunoreactive cytoplasm are observed in the intermuscular connective tissue area of the vagina. M: smooth muscle

Scale bar $=50 \mu \mathrm{m}$ 


\section{Distribution of NP immunoreactive nerve fibres}

In the shell gland and the vagina the density of NP immunoreactive nerve fibres was higher in the tunica muscularis than in the lamina propria-submucosa (Table 1). In all the oviductal regions, the NP immunoreactive nerve fibres within the tunica muscularis ran parallel to the longitudinal axis of the smooth muscle cells (Fig. 2A). The intermuscular connective tissue area, located between the muscle layers of the tunica muscularis, contained several NP immunoreactive nerve bundles (Fig. 2B). These nerve bundles were in most cases associated with blood vessels. No NP immunoreactive nerve fibres were demonstrated within the blood vessel walls in any of the oviductal regions studied. A few large nerve bundles containing NP immunoreactivity were observed in the tunica serosa. These nerve bundles appeared to course independently of blood vessels.

\section{Distribution of NSE immunoreactive nerve fibres}

In general nerve fibres in the lamina propria-submucosa coursed parallel to the epithelium (Fig. 3A). In the shell gland and vagina the density of NSE immunoreactive nerve fibres appeared to be greater in the tunica muscularis than in the lamina propriasubmucosa (Table 1). The tunica muscularis in all the regions studied contained NSE-immunoreactive nerve fibres which were orientated parallel to the longitudinal axis of the smooth muscle cells.

Nerve bundles containing NSE immunoreactivity were observed in the intermuscular connective tissue area of the oviduct. In addition to coursing alongside blood vessels, NSE-immunopositive nerve fibres were seen within the walls of blood vessels (Fig. 3B). In all the oviducal regions studied, a few nerve bundles within the tunica muscularis and intermuscularconnective tissue area contained NSE-immunoreactive nerve cell bodies (Fig. $3 \mathrm{C}$ ). The nerve cell bodies occurred either singly or in small groups, and were characterized by the presence of abundant NSE-immunoreactive cytoplasm and a large vesicular nucleus with a prominent nucleolus. Occasionally, the nerve cell bodies appeared to be independent of nerve bundles (Fig. 3D). The frequency of occurrence of the nerve cell bodies did not appear to differ between the various oviductal regions.

A moderate number of NSE-immunoreactive nerve bundles was observed in the tunica serosa of the isthmus and shell gland, whilst few nerve bundles or nerve fibres were seen in the serosal layers of the other regions of the oviduct. In all cases nerve bun- dles within the tunica serosa did not appear to be accompanied by blood vessels.

\section{DISCUSSION}

The present study is the first documentation of nerve distribution in different regions of the ostrich oviduct. The neuronal markers used showed that the tunica serosa and the intermuscular connective tissue area contained predominantly nerve bundles, whilst the tunica muscularis and lamina propria-submucosa contained mainly isolated nerve fibres. Furthermore, the markers used indicated that nerve density is greater in the tunica muscularis and intermuscular connective tissue area, and less in the lamina propria-submucosa. These findings are in general agreement with previous studies in the domestic fowl (Gilbert \& Lake 1963; Costagliola et al. 1997) and the pigeon (Atoji et al. 2000). In addition, as noted by Gilbert \& Lake (1963), the nerve density in the shell gland and vagina is greater than in the more proximal regions of the oviduct. The large number of nerve fibres in the tunica muscularis of the shell gland and the vagina is undoubtedly important in the coordination of muscle contraction during oviposition. Interestingly, the results of the present study are contrary to the results of an electron microscopic study carried out in the quail oviduct in which it was demonstrated that very few nerve fibres were present in the tunica muscularis (Arjamaa \& Talo 1983). These findings are surprising as it is assumed that the tunica muscularis in the avian oviduct would have an extensive neural network to coordinate the transportation of the ovum. However, as explained by Arjamaa \& Talo (1983) the muscular contractions of the quail oviduct occur as a result of electrical activity induced as the ovum stretches the smooth muscle cells.

In the present study, PGP and NSE-immunoreactive nerve fibres were seen in the walls of blood vessels. Since both PGP and NSE are general neuronal markers, demonstrating both efferent and afferent nerves, it is possible that the nerves observed in the walls of the blood vessels were autonomic. Admittedly, the antibodies used precluded the identification of sympathetic and parasympathetic nerve fibres. However, research carried out by Sorger, Pittman \& Soderwell (1983) has shown the presence of a sympathetic innervation to blood vessels in the uterus of the hamster. Furthermore, in the pigeon nicotinamide adenine dinucleotide phosphate reduced diaphorase (NADPH-d)-reactive nerve fibres, which are known to be parasympathetic in nature, have been observed around blood vessels in the oviduct (Atoji et al. 2000). 
Likewise, a study on the innervation of the oviduct in the domestic fowl demonstrated a perivascular autonomic nerve network, which was thought to regulate blood flow (Costagliola et al. 1997).

In addition to having an influence on blood flow it is known that autonomic nerve fibres play a role in the regulation of glandular secretion. Indeed, a study of the uterine innervation in the mare indicated the presence of nerve fibres around endometrial glands (Bae et al. 2001). As the ostriches used in the present study were sexually immature with quiescent ovaries, developed tubular glands were not observed in the oviduct. A study using oviductal material from sexually mature ostriches is necessary to determine the innervation of oviductal tubular glands in this species.

The structure and location of nerve cell bodies in the ostrich oviduct correlated well with descriptions of similar cells in the domestic fowl (Gilbert \& Lake 1963; Costagliola et al. 1997). Gilbert \& Lake (1963) reported that in the domestic fowl single and paired nerve cell bodies were found in large nerve bundles in the intermuscular connective tissue area. Furthermore, by employing NADPH-d histochemistry Costagliola et al. (1997) were also able to demonstrate a few nerve cell bodies in the circular layer of the tunica muscularis. In the present study NSE immunohistochemistry demonstated the presence of nerve cell bodies in the intermuscular connective tissue area, as well as in the tunica muscularis. Furthermore, as in the domestic fowl (Gilbert \& Lake 1963), some nerve cell bodies appeared to occur independently of nerves. Interestingly, the nerve cell bodies identified in the present study were immunopositive for NSE, but not for PGP or NP.

In conclusion, the results of the study indicate that the oviduct of the ostrich has an extensive neural network, which was demonstrated by the neuronal markers PGP, NP and NSE.

\section{ACKNOWLEDGEMENTS}

The author thanks Ms M. Smit for technical advice. Prof. T.A. Aire's help in reviewing the manuscript is gratefully appreciated. The National Research Foundation of South Africa (Thuthuka programme) and the University of Pretoria funded the study.

\section{REFERENCES}

ALM, P., LUNDBERG, L.M., WHARTON, J. \& POLAK, J.M. 1988a. Ontogenetic development of the guinea pig uterine innerva- tion. An immunohistochemical study of different neuronal markers, neuropeptides and S-100 protein. Histochemistry, 90:19-24.

ALM, P., LUNDBERG, L.M., WHARTON, J. \& POLAK, J.M. $1988 \mathrm{~b}$. Organization of the guinea pig uterine innervation. Distribution of immunoreactivities for different neuronal markers. Effects of chemical- and pregnancy-induced sympathectomy. Histochemical Journal, 20:290-300.

ARJAMAA, O. \& TALO, A. 1983. Description of the structural control systems of ovum transport in the quail oviduct. Acta Physiologica Scandinavica, 117:405-410.

ATOJI, Y., MIZUTANI, K., YAMAMOTO, Y. \& SUZUKI, Y. 2000. Innervation of the pigeon oviduct: correlation of NADPH diaphorase with acetylcholinesterase, tyrosine hydroxylase, and neuropeptides. Autonomic Neuroscience, 84:1-7.

BAE, S.E., CORCORAN, B.M. \& WATSON, E.D. 2001. Organisation of uterine innervation in the mare: distribution of immunoreactivities for the general neuronal markers protein gene product 9.5 and PAN-N. Equine Veterinary Journal, 33:323325.

BRAUER, M.M., LLODRA, J., SCORZA, M.C., CHAVEZ, R., BURNSTOCK, G., THRASIVOULU, C. \& COWEN, T. 1999. Differential effects of prepubertal chronic oestrogen treatment on the synthesis of noradrenaline in uterine myometrial and perivascular sympathetic nerves. International Journal of Developmental Neuroscience, 17:295-303.

COSTAGLIOLA, A., MAYER, B., VITTORIA, A., CARRESE, E., LAMANNA, C. \& CECIO, A. 1997. NADPH-diaphorase-, nitric oxide synthase- and VIP-containing nerve structures in the hen oviduct: a histochemical and immunohistochemical study. Archives of Histology and Cytology, 60:245-256.

GILBERT, A.B. \& LAKE, P.E. 1963. Terminal innervation of the uterus and vagina of the domestic hen. Journal of Reproduction and Fertility, 5:41-48.

HAASE, E.B., BUCHMAN, J., TIETZ, A.E. \& SCHRAMM, L.P. 1997. Pregnancy-induced uterine neuronal degeneration in the rat. Cell Tissue Research, 288:293-306.

KHONG, T.Y., TEE, J.H. \& KELLY, A.J. 1997. Absence of innervation of the uteroplacental arteries in normal and abnormal pregnancies. Gynecologic and Obstetric Investigation, 43: 89-93.

KRAUTWALD-JUNGHANNS, M.E., KOSTKA, V.M. \& HOFBAU$E R, H .1998$. Observations of the significance of diagnostic findings in egg-binding of psittaciformes. Veterinary Record, 143:498-502.

LUNDBERG, L.M., ALM, P., WHARTON, J. \& POLAK, J.M. 1988. Protein gene product 9.5 (PGP 9.5). A new neuronal marker visualizing the whole uterine innervation and pregnancy-induced and developmental changes in the guinea pig. Histochemistry, 90:9-17.

ROSSKOPF, W.J. \& WOERPEL, R.W. 1984. Egg binding in caged and aviary birds. Modern Veterinary Practice, 65:437440.

SORGER, T., PITTMAN, R. \& SODERWELL, A.L. 1983. Principal features of the nerve supply to the ovary, oviduct and tubal third of the uterus in the golden hamster. Biology of Reproduction, 28:461-482.

TALO, A. \& KEKALAINEN, R. 1976. Ovum promotes its own transport in the oviduct of the Japanese quail. Biology of Reproduction, 14:186-189.

WECHSUNG, E. \& HOUVENAGHEL, A. 1988. Myoelectrical activity changes in uterus and vagina during oviposition in the conscious domestic hen. Poultry Science, 67:1615-1618. 
WROBEL, K.H. \& KUJAT, R. 1993. The bovine tubouterine junction: general innervation pattern and distribution of adrenergic, cholinergic and peptidergic nerve fibers. Cell Tissue Research, 274:493-501.

ZOUBINA, E.V., MIZE, A.L., ALPER, R.H. \& SMITH, P.G. 2001. Acute and chronic estrogen supplementation decreases uter- ine sympathetic innervation in ovariectomized adult virgin rats. Histology and Histopathology, 16:989-996.

ZOUBINA, E.V. \& SMITH, P.G. 2001. Sympathetic hyperinnervation of the uterus in the estrogen receptor alpha knock-out mouse. Neuroscience, 103:237-244. 